\title{
Synthesizing the Relationship between Reported Dissonance and Post-Purchase Responses in High Involvement Decisions Using Structural Equation Modeling (SEM)
}

\author{
Sanjana Brijball Parumasur, Nabendra Parumasur \\ University of KwaZulu-Natal (Westville Campus), Durban, South Africa \\ brijballs@ukzn.ac.za, parumasurn1@ukzn.ac.za
}

\begin{abstract}
This study develops and validates a scale to assess the impact of reported dissonance on postpurchase responses (attitude change, trivialisation, selective exposure, justification) respectively and applies the instrument to high involvement consumers. A sample of 200 new motor vehicle buyers who purchased from a leading and reputable motor vehicle company in KwaZulu-Natal, South Africa, was drawn using stratified random sampling based on range of motor vehicle (bottom, middle, top) and month of purchase. Initially, exploratory factor analysis (EFA) was used to extract the factors. The reliability of the modified questionnaire was then assessed using Cronbach's Coefficient Alpha. Thereafter, confirmation factor analysis (CFA) was used to establish if the measurement model is a good fit and to develop and test the model structure in SEM, which generated a good model fit. Pearson $r$ was computed to assess the relationship amongst the dimensions. Using structural equation modelling, the results support significant inverse relationships between reported dissonance and attitude change, trivialisation and justification respectively. Whilst the inverse relationship between reported dissonance and selective exposure was supported using correlation, it was not confirmed using SEM. Recommendations, based on the findings, are presented and are directed at reducing reported dissonance and effectively managing post-purchase interactions and responses.
\end{abstract}

Keywords: Post-purchase evaluation, reported dissonance, attitude change, trivialisation, selective exposure, justification

\section{Introduction}

In an environment of endless choices marketers have realised that it is easier to keep existing customers than to attract new ones. Hence, against this experience, marketers need to understand the consumer after the purchase because post-purchase evaluation channels post-purchase attitude (cognition, feeling, behaviour) towards the product or brand purchased. It is important to note that post-purchase response will depend on the type of consumer decision and therefore, differ for habitual, limited and extended decision-making. This study therefore, aims to synthesize the delicate relationship between post-purchase evaluation and response after the purchase of a motor vehicle. In particular, this study focuses on negative post-purchases responses and assesses the impact of reported dissonance on post-purchase responses (attitude change, trivialization, selective exposure, justification) respectively. Reported dissonance creates unpleasant feelings, psychological discomfort and stress for the customer which based on the theory of cognitive dissonance by Festinger (1957) would mean that the customer will engage in activities to restore consistency. When a customer engages in an expensive and long term purchase such as a motor vehicle purchase and experiences dissonance he/he may change his/her attitude in favour of the purchased brand (attitude change), trivialize the importance of the feature which does not meet his/her satisfaction in the purchased product (trivialization), choose to read more literature (brochures/newspapers) about the purchased product and ignore that of competitor products that were foregone (selective exposure) or justify the purchase, for example, that the foregone alternatives were not value for money (justification). The consumer may engage in one or more of these activities in attempts to reduce stress brought about by the dissonance in attempts to reintroduce balance.

The need for decision-making and, influencing variables: The primary decision that consumers engage in is whether to spend or to save. This decision will be determined by several influences, which can be divided into internal or individual influencing variables (needs, motives, personality, perception, learning, attitudes) and external or environmental influencing variables (culture and sub-culture, social influences, reference groups, family, economic demand factors, business and marketing influences) (Blackwell, Miniard \& Engel, 2006; Brijball Parumasur \& Roberts-Lombard, 2012; du Plessis \& Rousseau, 2003; Hawkins, Best \& Coney, 
2001; Hawkins \& Mothersbaugh, 2013; Hoyer, MacInnis \& Pieters, 2013; Koklič \& Vida, 2009; Peter \& Olson, 2010; Schiffman \& Kanuk, 2014; Solomon, Bamossy, Askegaard \& Hogg, 2006). Evidently, consumers do not function in isolation (Brijball, 2003) as these variables continuously and concurrently intercept and have a significant impact on the consumer's ultimate choice. This means that in any decision process, the consumer draws external information and assimilates it with his/her internal variables such as needs, attitudes and perceptions. The choice outcome may also be influenced by the past, the act of recalling and personality factors (Brijball, 2000). Many of these learned behaviors and ways of thinking are unconscious (Blackwell et al., 2006). Over and above past product experiences, the expectation of forthcoming outcomes of an action may also impact the selection in a current purchase situation dictated by choice alternatives and a given context (du Plessis \& Rousseau, 2003). The consumer decision-making process comprises of five stages, namely, recognizing the problem, searching for alternatives, evaluating the alternatives, making the purchase and post-purchase utilization and assessment, and involves both psychological and physical activities. Since the stages in the process are not necessarily linear but fluid and rather intertwined (Koklič \& Vida, 2009; Schiffman \& Kanuk, 2014), the consumer can launch into any stage or activity in the process and even bypass stages depending on the type of decision.

Type of decision-making: The concepts of internal and external search imply that the type of decisionmaking determines the extent of search effort. A distinction can be made between habitual, limited and extended decision-making with are respectively associated with minimal, limited and extensive search effort. Habitual decision-making occurs when the consumer purchases an item without considering alternatives largely due to prior product experience and satisfaction thereby decreasing the need for information search and further evaluation and can be categorized into brand loyalty and repeat purchase behaviour. Limited decision-making takes place when the consumer engages in little alternative evaluation. The individual engages in extensive internal and external information search, often uses numerous sources and thoroughly evaluates multiple alternatives in extended decision-making (Dubey, 2014; Hansen, 2005; Hoelzl, Pollai \& Kastner, 2011; Koklič \& Vida, 2009; Peter \& Olson, 2010). In other words, extended decision-making involves a high level of complexity and extensive problem-solving. Extended decision-making is therefore characterized by conscious planning especially when durable products are purchased and when the purchase is important as it requires a large capital outlay (van der Walt, Strydom, Marx \& Jooste, 1996). As one moves from habitual to limited to extensive decision-making the level of consumer involvement (motivation to act) and product involvement (importance of product class to self-identity thereby triggering strong attitudes and preferences) also increases (Wilkie, 1990; Traylor, 1981). Involvement is the extent of personal relevance of the brand or product which influences the individual's perception of its value and importance to the consumer (Peter \& Olson, 2010). Hence, in low involvement the consumer does not identify with the product, care about it, nor consider it to be essential to his/her belief system, and may passively accepts information and may act without thinking (Horton, 1984). In high involvement decision-making, however, the consumer perceives the product as being important to his/her self image, will engage in greater information search and in extensive thought processes. Even after the purchase, the individual is likely to engage in detailed evaluation of the purchase.

\section{Theory underpinning the study}

Festinger's (1957) cognitive dissonance theory which was later revised by Elliot Aronson (1968) underpins the study. The original theory claims that the individual consumer strives toward consistency within the self, that is, to attain inner balance among thought, feelings, values and actions. According to Brehm (1992), the theory assumes a strong relationship between cognitions about behaviour and the environment. The underlying concept of congruence is the understanding that an individual's thinking, perceptions, attitudes and actions interact in logical and profound ways. Prior to making any major decision, the consumer encounters conflicts between two or more alternatives. Even after making the decision and engaging in purchase behaviour, the consumer evaluates the wisdom of the decision. However, when inconsistency occurs post-decision and post-action, dissonance arises and creates a noxious state thereby, triggering pressures to eliminate or reduce it (Festinger, 1957; Zajonc, 1960). This study therefore, explores the strategies that consumers in high-involvement purchases adopt in attempts to reduce dissonance. Numerous studies have been undertaken to evaluate the use of attitude change to restore consistency (Assael, 1992; 
Cooper \& Fazio, 1984; Ginter, 1974; Goethals and Cooper, 1975; Kunda, 1990; Wright, Rule, Ferguson, McGuire \& Wells, 1992; Zaltman \& Wallendorf, 1983). Researchers have also explored consumers' efforts to attain consonance through trivialization (Simon, Greenberg \& Brehm, 1995) whilst others have investigated the use of selective exposure (Bell, 1967; Brown, 1961; Ehrlick, Guttman, Schonbach \& Mills, 1957; Engel, 1963; Lowe \& Steiner, 1968; Lord, Ross \& Lepper, 1979; Venkatesan, 1973). Furthermore, researchers have studied consumers' use of justification in attempts to reduce stress and felt dissonance (Aronson, 1968; Brehm \& Cohen, 1962; Frey, Kumpf, Irle \& Gniech, 1984; Geva \& Goldman, 1991; Greenwald, 1969; Wicklund \& Brehm, 1976; Zajonc, 1960). Evidently, the majority of the studies relating to dissonance reduction strategies, though very enlightening, useful and having laid the foundations for future research, have been conducted a while ago. Furthermore, there are no studies, to the researchers' knowledge, that have explored the use of all these strategies (attitude change, trivialization, selective exposure and justification) against each other in one study, which the current study aims to do.

Post-purchase evaluation: Whilst the decision-making process involves various stages, this study focuses on how the consumer in extended decision-making feels after the purchase and therefore, embeds the study in the domain of post-purchase evaluation. Post-purchase evaluation relates to the consumer's assessment of the how the purchased product or service is performing in terms of the set criteria (Peter \& Olson, 2010). It is the consumer's interpretation of the purchase outcome. Consumers prefer to believe that the purchase decision made was the best one but the insufficient information encountered seldom allows such an unequivocal assurance. The lack of adequate information and the lack of technical knowledge, where required, make it difficult for consumers to thoroughly evaluate alternative products available in the market thereby resulting in uncertainty regarding the correctness of the decision made.

The phase after the purchase incorporates various forms of psychological processes that consumers can undergo after the purchase. Whilst it is maintained (Blackwell et al., 2006; Walters \& Bergiel, 1989; Wilkie, 1990 ) that the result of purchasing can either be positive (satisfaction) or negative (dissatisfaction) and involve an emotional response to the evaluation of the purchase, du Plessis and Rousseau (2003) include another possible outcome in the form of a neutral assessment (Donoghue, de Klerk \& Ehlers, 2008; Laufer, 2002; Ndubisi \& Ling, 2006; Schiffman \& Kanuk, 2014). Before the act of purchase, consumers develop expectations regarding the consequences of the purchases. The feedback from the purchase serves to either confirm or reject these expectations. Satisfaction occurs when the outcome meets the consumer's expectations and when the chosen alternative falls short of meeting expectations in important ways such that unconfirmed expectations exits, dissatisfaction occurs giving rise to cognitive inconsistency.

After a dissatisfying purchase, the consumer's reaction may be verbal or behavioral (du Plessis \& Rousseau, 2003). Whilst a positive verbal response may cognitively reinforce purchase intentions, negative ones may result in rumors. Equally dangerous to the latter is indifferent verbal responses or responses which can evoke suspicion among other potential consumers. Positive behavioral responses generally relate to repeat buying behavior or brand loyalty when satisfaction is experienced. A behavioral complaint that is negative can be private (for example, warning friends and family) or public (complaining to the organization and demanding redress or taking legal action) or brand switching in the case of dissatisfaction and also negative word-of-mouth communication (Ladhari, 2007; Soscia, 2007; Zeithaml, Bitner \& Gremler, 2006). A neutral behavioral response incorporates inertia (because it is not worth the time and trouble to engage in evaluation) or impulse buying in the case of indifference (Assael, 1992).

Sometimes consumers experience conflict after the purchase as they are unsure of the correctness of the decision. This doubt or anxiety is particularly prevalent when the consumer engages in a tough, important and enduring decision. This type of anxiety is called post-purchase dissonance which occurs because making a rather permanent commitment to a selected alternative demands foregoing the attractive characteristics of the unchosen alternatives (Hawkins et al., 2001; Hoelzl et al., 2011; Lamb, Hair, McDaniel, Boshoff \& Terblanche, 2008; Solomon et al., 2006) and is therefore, a violation of expectancy. In some cases consumers may changes their attitudes and thinking in attempts to minimize the dissonance. They will try to reestablish a balance in their psychological make-up by searching for information that supports their decision or by changing information about the product/service that creates the anxiety, thereby engaging in cognitive 
dissonance (du Pleassis \& Rousseau, 2003). Each consumer has numerous cognitions about him/herself or other people and the decisions he/she makes. If these elements follow logically from the other, 'consonant cognitions' exist but if there is logical inconsistency 'dissonant cognitions' arise (Wilkie, 1990). Postpurchases responses are significantly impacted by economic demand concerns because the more expensive the product, the greater will be the financial risk and the more intensive will be level of satisfaction or dissatisfaction. It is important to note that the current study focuses on negative post-purchase evaluation, that is, reported dissonance rather than satisfaction.

Since dissonance produces unpleasant feelings and psychological discomfort, the individual will take action to reduce the extent of dissonance experienced. People usually reduce cognitive dissonance by changing their attitudes to reestablish congruence with their behaviour and this often entails reevaluating the chosen brand more favorably than alternatives (Brijball Parumasur \& Roberts-Lombard, 2012; Schiffman \& Kanuk, 2014). Furthermore, consumers may decrease the significance they attach to the components in the dissonant relations through the use of trivialization or alternatively, cognitions can be added to make the attitudebehaviour relationship seem more rational, logical or justifiable. Simon, Greenberg \& Brehm (1995) noted three conditions under which trivialization are more likely than attitude change:

a) When the preexisting attitude is very important, consumers trivialize the cognitions rather than change their attitudes.

b) Consumers are more likely to trivialize when the opportunity to evaluate the salience of the cognitions precedes the opportunity to reflect their attitude.

c) After one engages in purchases that run contrary to one's attitude, making important values or issues salient results in trivialization rather than attitude change.

Another dissonance reduction strategy is justification meaning that when an attractive alternative is rejected, the dissonance which arises can be reduced by justifying the decision (Heitmann, Lehmann \& Hermann, 2007; Wang \& Shukla, 2013). This means that consumers will explain why engaging in a certain purchase surpasses the reasons against performing it thereby making the selected alternative seem even more favourable than it originally was by finding something attractive about it. This makes the chosen alternative more attractive and decreases the attractiveness and value of the unchosen alternatives thereby causing greater variance between the purchased item and the unchosen options. In addition, a consumer experiencing cognitive dissonance may attempt to reduce it by engaging in selective exposure. Dissonance theory maintains that consumers are inclined to encounter attitude-consonant information and to steer away from attitudedissonant information in attempts to establish cognitive consonance and avoid cognitive dissonance. Thus, in managing dissonance consumers are likely to emphasize the positive features of the chosen alternative and highlight the negative qualities of unchosen options. Therefore, to avoid confronting dissonance, consumers will:

a) Avoid exposure to or ignore dissonant or potentially damaging information.

b) Seek out positive information or attempt to be exposed to information that adds consonant elements.

c) Weaken existing dissonant elements.

d) Reduce the salience of the issue which led to dissonance.

e) Resort to a combination of the aforementioned strategies (Assael, 1992; du Plessis \& Rousseau, 2003; Engel \& Blackwell, 1982; Frey, 1982; Hoelzl et al., 2011).

Advertising provides an avenue of relief to post-purchase dissonance. Numerous researchers (Brown, 1961; Ehrlich, Guttman, Schonbach \& Mills, 1957) substantiate the existence of enhanced advertising readership by recent motor vehicle buyers. Readership of motor vehicle advertisements tends to be higher among owners of a specific make than among non-owners (Bell, 1967; Brown, 1961; Ehrlich et al., 1957). However, Engel (1963) does not explain this strategy of dissonance reduction in terms of selective exposure but defines it in terms of figure-and-ground relationships explaining that advertisements that previously escaped the consumer's attention are now noticed because after the purchase of the motor vehicle the buyer has become more alert about it and adds that the consumer will not necessarily avoid unpleasant information. Nevertheless, Engel and Blackwell (1982) reiterates that the consumer encountering dissonance will 'buttress' the selected alternative by obtaining additional information. During the process of post-purchase evaluation, post-purchase learning takes places as the consumer through his/her new experience discovers 
new information, adjusts attitudes and stores the new knowledge in memory as inputs for future purchases thereby providing feedback for future purchases. Hence, although post-purchase assessment is the last stage, the process of decision-making does not necessarily end. The information gained as a result of purchase and post-purchase evaluation is stored in the individual's memory as part of his/her experiences only to be recalled when entering into another purchase decision-making process. Therefore, consumer buying decisions are the result of rational decision-making and involve problem recognition, search and processing of information, evaluation of alternative, response and post-purchase evaluation and behaviour (du Plessis \& Rousseau, 2003). The only variation in different purchases is the emphasis the individual places on the different steps in the process of decision-making and this depends on the subjective importance attached by the consumer to the purchase and his/her level of involvement.

\section{Methodology}

Approach: The study adopts a quantitative, cross-sectional research design that aims to assess the relationship between negative post-purchase evaluation (reported dissonance) and post-purchase response (attitude change, trivialisation, selective exposure, justification) respectively.

Participants: A sample of 200 brand new motor vehicle buyers was drawn using the stratified random sampling technique. Only new motor vehicle buyers (within Kwa-Zulu Natal, South Africa) who concluded their purchases in one major, reputable and leading motor vehicle manufacturing company were considered. The sample for this study was proportionately stratified on the basis of two controls or criteria (range of motor vehicle purchased, month of purchases) since these sub-groups are expected to have different parameters on the potential to experience cognitive dissonance and the level of reported dissonance. Representativeness was achieved by drawing a proportional percentage of consumers in the different ranges of motor vehicles purchased. The motor vehicles purchased were divided on the basis of price into 'bottom of the range' ( $47.25 \%$ of sample), 'middle of the range' (33.75\%) and 'top of the range' (19\%). Secondly, time of purchases served as a further control as only those buyers who owned their new vehicles for a period of up to seven months were included in the study to avoid cognitive intrusion. The adequacy of the sample was determined on the basis of the Kaiser-Olkin Measure of Sampling Adequacy (0.912) and Bartlett's Test of Sphericity (4481.579; $<0.000$ ), which respectively showed suitability and significance. The results indicate that the normality and homoscedasticity preconditions are satisfied.

Instruments: The measuring instrument was a self-developed, preceded, standardised questionnaire comprising of Sections A and B. Section a included motor vehicle specific variable, namely, range of vehicle (bottom, middle and top of range) and month of purchases. Section B included 8 items relating to reported dissonance which comprised of 3 items measuring cognitive dissonance and 5 items tapping into anxiety experienced. Section B also included 20 items relating to post-purchase response which comprised of 5 items measuring attitude change, 4 items tapping into trivialisation, 7 items exploring selective exposure and 4 items measuring justification as a potential post-purchase response. The dimensions of reported dissonance and post-purchase response were measured using a 5 point Likert scale.

Procedure: The mail survey was used and hence, the questionnaires were self-administered. The questionnaire, together with a covering letter indicating the purpose and need for the study was posted to sample subjects, using the postal services. Each respondent was contacted telephonically informing them of the arrival of the questionnaire, already posted. The questionnaires were numbered so as to follow up on non-responses. Those who did not respond within two weeks were again telephoned to remind them of the purpose of the study, so as to ensure a suitable response rate. A self-addressed envelope and stamp was provided so respondents need not bear a financial cost, thereby increasing the return rate.

Statistical Analysis: When designing the initial questionnaire, face and content validity were prioritised by including all aspects of reported dissonance that related to anxiety and cognitive dissonance as these items surfaced repeatedly in terms of negative post-purchase evaluation. In addition, all possible post-purchase responses that surfaced in the literature review relating to post-purchase response were included, namely, attitude change, trivialisation, selective exposure and justification. The validity of the questionnaire was 
statistically assessed using Exploratory Factor Analysis (EFA) to identify and extract the factors and Confirmatory Factor Analysis (CFA) to establish if the measurement model is a good fit. The reliability of the modified questionnaire was statistically assessed using Cronbach's Coefficient Alpha and generated a high level of inter-item consistency (Cronbach's Alpha $=0.7$ ). The results of the study were analysed using the Pearson Product Moment Correlation and structural equation modelling (SEM) using AMOS. SEM was used to assess the relationship between reported dissonance and attitude change, trivialisation, selective exposure and justification respectively. Hence, SEM 1was used to draw conclusions on the following hypotheses:

$H_{1}$ : There is a significant, inverse relationship between reported dissonance and attitude change.

$\mathrm{H}_{2}$ : There is a significant, inverse relationship between reported dissonance and trivialisation.

$H_{3}$ : There is a significant, inverse relationship between reported dissonance and selective exposure.

$H_{4}:$ There is a significant, inverse relationship between reported dissonance and justification.

An inverse relationship between reported dissonance and the post-purchase responses is hypothesised because it is believed that as the level of reported dissonance increases, the buyer's motivation to engage in the post-purchase response (attitude change, trivialisation, selective exposure, justification) decreases. Basic parameters for the interpretation of SEM are provided in Table 1.

Table 1: Basic Parameter for the interpretation of SEM

\begin{tabular}{|c|c|c|}
\hline Index & Abbreviation & Parameter for interpretation \\
\hline $\begin{array}{l}\text { Chi-square/degrees } \\
\text { of freedom ratio }\end{array}$ & CMIN/DF & Should be 2 or less than 2 to reflect a good fit (Ullman, 2001). \\
\hline $\begin{array}{l}\text { Goodness of fit } \\
\text { index }\end{array}$ & GFI & Should be greater than 0.9 (Byrne, 1994). \\
\hline $\begin{array}{l}\text { Root Mean Square } \\
\text { Error } \quad \text { of }\end{array}$ & $\begin{array}{l}\text { RMS } \\
\text { RMSEA }\end{array}$ & $\begin{array}{l}\text { Should be less than } 0.08 \text { (Browne \& Cudeck, 1993) but should not } \\
\text { exceed } 0.08 \text { (Hu \& Bentler, 1999). }\end{array}$ \\
\hline $\begin{array}{l}\text { Approximation } \\
\text { Comparative fit } \\
\text { index }\end{array}$ & CFI & Should exceed 0.93 (Bryne, 1994) \\
\hline $\begin{array}{l}\text { Root mean square } \\
\text { residual }\end{array}$ & RMR & $\begin{array}{l}\text { The smaller the RMR, the better the model. RMR smaller than } 0,5 \\
\text { indicates good fit (Zen, 2007). }\end{array}$ \\
\hline Tucker Lewis Index & TLI & $\begin{array}{l}\text { TLI greater than or equal to } 0.9 \text { indicates acceptable model fit (Zen, } \\
\text { 2007). }\end{array}$ \\
\hline
\end{tabular}

\section{Results}

Table 1 A: Exploratory Factor Analysis generating pattern matrix

\begin{tabular}{lllll}
\hline Item Code & Component & & $\mathbf{3}$ & $\mathbf{4}$ \\
RD3 & $\mathbf{1}$ & $\mathbf{2}$ & & $\mathbf{5}$ \\
RD2 & 0.890 & & & \\
RD4 & 0.879 & & & \\
RD5 & 0.864 & & & \\
RD6 & 0.860 & & & \\
RD7 & 0.840 & & & \\
RD8 & 0.838 & & & \\
RD1 & 0.827 & & & \\
& & & & \\
JUST2 & & 0.805 & & \\
JUST3 & & 0.722 & & \\
JUST4 & & 0.682 & & \\
JUST1 & & 0.638 & & \\
AC1 & & 0.606 & \\
AC2 & & 0.645 & & \\
\hline
\end{tabular}




\begin{tabular}{llll}
\hline TRIV4 & 0.811 & & \\
TRIV2 & 0.804 & & \\
TRIV3 & 0.800 & & \\
TRIV1 & 0.683 & & \\
AC3 & & 0.684 & \\
AC4 & & 0.681 & \\
AC5 & & 0.649 & \\
SE6 & 0.618 & \\
SE7 & 0.716 & 0.847 \\
SE4 & & 0.794 \\
SE2 & & 0.757 \\
SE1 & & 0.585 \\
SE5 & & \\
SE3 & & & 0.496 \\
\hline
\end{tabular}

Measurement model and factor structure: The study assesses the relationship between reported dissonance and attitude change, trivialisation, selective exposure and justification respectively using a self-developed questionnaire comprising of 28 items relating to these five constructs. Exploratory factor analysis with varimax rotation was conducted to assess how the key constructs cluster (Table $1 \mathrm{~A}$ ). From Table $1 \mathrm{~A}$, it is evident that 8 items (RD3, RD2, RD4, RD5, RD6, RD7, RD8 and RD1) as highlighted under Factor 1 were included in the study to measure reported dissonance. Four items in Factor 2 were included but the $5^{\text {th }}$ and $6^{\text {th }}$ items (AC1 and AC2) were excluded as the items related to attitude change. Hence, the 5 items selected in Factor 2 relate to the post-purchase response called justification. The 4 items that loaded significantly in Factor 3 relate to the post-purchase response of trivialization. Three items in Factor 4 were included but the $4^{\text {th }}$ and $5^{\text {th }}$ items (SE6 and SE7) were excluded as the items related to selective exposure. Hence, the 3 items selected in Factor 4 relate to the post-purchase response called attitude change. The 5 items that loaded significantly in Factor 5 relate to the post-purchase response of selective exposure. The aforementioned Factors have eigenvalues $>1$ and account for $70.12 \%$ of the total variance. The selected items, statements and their items loadings are presented in Table 2.

Table 2: Selected Items, Statements and Item Loadings

\begin{tabular}{|c|c|c|c|}
\hline $\begin{array}{l}\text { Item } \\
\text { Code }\end{array}$ & $\begin{array}{l}\text { Statement }(\mathrm{RD}=\text { Reported dissonance, JUST = Justification, TRIV } \\
=\text { Trivialization, } \mathrm{AC}=\text { Attitude change, } \mathrm{SE}=\text { Selective exposure) }\end{array}$ & $\begin{array}{l}\text { Item } \\
\text { Loading }\end{array}$ & Communalities \\
\hline RD1 & $\begin{array}{l}\text { I wish I had selected an alternative make of car when I was making my } \\
\text { decision to purchase. }\end{array}$ & 0.827 & 0.779 \\
\hline RD2 & My choice of car has left me discontent. & 0.879 & 0.827 \\
\hline RD3 & I wish I could return my car for another make. & 0.890 & 0.868 \\
\hline RD4 & When I think of the choice of car made, I feel tense and disappointed. & 0.878 & 0.835 \\
\hline RD5 & I feel uncomfortable about the decision I made. & 0.864 & 0.835 \\
\hline RD6 & I feel I made the wrong decision regarding the motor vehicle I chose. & 0.860 & 0.886 \\
\hline RD7 & My choice of car makes me feel that I have not made the best decision. & 0.840 & 0.820 \\
\hline RD8 & I still wonder whether I made the correct decision. & 0.838 & 0.804 \\
\hline AC3 & $\begin{array}{l}\text { Any doubts about the correctness of my decision have been overcome } \\
\text { by positive feedback obtained from my family. }\end{array}$ & 0.684 & 0.603 \\
\hline AC4 & $\begin{array}{l}\text { Positive feedback from friends regarding the car I chose has convinced } \\
\text { me of the correctness of my decision. }\end{array}$ & 0.681 & 0.685 \\
\hline AC5 & $\begin{array}{l}\text { Any doubts about the correctness of my decision have been overcome } \\
\text { by positive feedback from advertisements reflecting the performance } \\
\text { of the car I chose. }\end{array}$ & 0.649 & 0.576 \\
\hline TRIV1 & $\begin{array}{l}\text { The positive features of unselected alternatives, that are non-existent } \\
\text { in my car, are not important to me. }\end{array}$ & 0.683 & 0.703 \\
\hline TRIV2 & $\begin{array}{l}\text { The positive features of unselected alternatives, that are non-existent } \\
\text { in my car, are unnecessary items that increase the price of the car. }\end{array}$ & 0.804 & 0.757 \\
\hline
\end{tabular}




\begin{tabular}{|c|c|c|c|}
\hline TRIV3 & $\begin{array}{l}\text { The positive features of unselected alternatives, that are non-existent } \\
\text { in my car, are trivial. }\end{array}$ & 0.800 & 0.754 \\
\hline TRIV4 & $\begin{array}{l}\text { The positive features of unselected alternatives, that are non-existent } \\
\text { in my car, are not part of my needs. }\end{array}$ & 0.811 & 0.728 \\
\hline SE1 & I only read motor vehicle advertisements reflecting the car I bought. & 0.757 & 0.647 \\
\hline SE2 & $\begin{array}{l}\text { I avoid people who are likely to talk negatively about the car I } \\
\text { purchased. }\end{array}$ & 0.794 & 0.659 \\
\hline SE3 & $\begin{array}{l}\text { People who express negative views about the car I bought do so out of } \\
\text { ignorance. }\end{array}$ & 0.496 & 0.404 \\
\hline SE4 & $\begin{array}{l}\text { I do not read advertisements reflecting other makes of vehicles, other } \\
\text { than the one I selected. }\end{array}$ & 0.867 & 0.776 \\
\hline SE5 & I do not give attention to negative views about my car. & 0.585 & 0.451 \\
\hline JUST1 & Considering my finances, my choice of car is the most suitable one. & 0.638 & 0.550 \\
\hline JUST2 & It is easy for me to explain why I chose the car I did. & 0.805 & 0.770 \\
\hline JUST3 & $\begin{array}{l}\text { The excellent performance of my car outweighs the price and effort } \\
\text { expended. }\end{array}$ & 0.722 & 0.710 \\
\hline JUST4 & $\begin{array}{l}\text { I believe that 'I got good value for money' by choosing the make of car } \\
\text { that I did. }\end{array}$ & 0.682 & 0.748 \\
\hline
\end{tabular}

The final 24 item questionnaire, therefore, defined reported dissonance in terms of 8 items, attitude change using 3 items, trivialization in terms of 4 items, selective exposure using 5 items and justification in terms of 4 items and the average communalities after extraction is 0.72 . The overall final questionnaire comprising of negative post-purchase evaluation and post-purchase response items reflected a high level of inter-item consistency (Cronbach's Alpha $=0.755$ ) with dimensional reliabilities being very strong: Reported dissonance $(\alpha=0.970)$, Attitude change $(\alpha=0.822)$, Trivialisation $(\alpha=0.871)$, Selective exposure $(\alpha=0.782)$ and Justification $(\alpha=0.866)$. Thereafter, confirmatory factor analysis (CFA) was used to verify the measurement model. Model identification was attained, and the indices for global fit reflects that the model sufficiently represented the data with $\mathrm{CMIN} / \mathrm{DF}=1.714, \mathrm{GFI}=0.856, \mathrm{RMSEA}=0.060$ and a comparative fit (CFI) of 0.955. CMIN/DF should ideally be 2 or less than 2 (Ullman, 2001) to reflect a good fit, GFI should be $>0.9$ (Bryne, 1994), RMS or RMSEA should be $<0.08$ (Browne \& Cudeck, 1993) but should not exceed 0.08 (Hu \& Bentler, 1999) and CFI should exceed 0.93 (Byrne, 1994). Bollen (1989) emphasizes that these criteria simply serve as guidelines. Hence, the model adequately represents the input data particularly taking cognisance of the large sample of 200 motor vehicle consumers being studied (Brijball Parumasur \& Parumasur, 2016). It was hypothesised that:

$H_{1}$ : There is a significant, inverse relationship between reported dissonance and attitude change.

$\mathrm{H}_{2}$ : There is a significant, inverse relationship between reported dissonance and trivialisation.

$H_{3}$ : There is a significant, inverse relationship between reported dissonance and selective exposure.

$H_{4}$ : There is a significant, inverse relationship between reported dissonance and justification.

Correlations between the constructs are reflected in Table $2 \mathrm{~A}$.

Table 2 A: Pearson Correlations of the dimensions

\begin{tabular}{|c|c|c|c|c|}
\hline \multirow{2}{*}{ Dimension } & \multicolumn{4}{|c|}{ Post-purchase response } \\
\hline & Attitude change & Trivialisation & Selective exposure & Justification \\
\hline $\begin{array}{l}\text { Reported } \\
\text { dissonance }\end{array}$ & $-0.525^{*}$ & $-0.461 *$ & $-0.119 *$ & $-0.717^{*}$ \\
\hline
\end{tabular}

Table 2 A reflects that there is a significant, inverse and moderate relationship between reported dissonance and attitude change at the $1 \%$ level of significance. Hence, hypothesis 1 may be accepted. Furthermore, there is a significant, inverse and moderate relationship between reported dissonance and trivialisation at the $1 \%$ level of significance. Hence, hypothesis 2 may be accepted. Table 2 also reflects a significant, inverse but weak relationship between reported dissonance and selective exposure at the $1 \%$ level of significance. 
Hence, hypothesis 3 may be accepted. In addition, there is a significant, inverse and strong relationship between reported dissonance and justification at the $1 \%$ level of significance. Hence, hypothesis 4 may be accepted. It is evident that as reported dissonance increases the post-purchase response, irrespective of form (attitude change, trivialisation, selective exposure, and justification), decreases.

Table 3: Standardised regression coefficients of the variables

\begin{tabular}{lccl}
\hline $\begin{array}{l}\text { Dimension } \\
\text { Reported dissonance }\end{array}$ & Estimate & S.E. & P \\
\hline Attitude change & -0.522 & 0.078 & $0.000^{*}$ \\
Trivialization & -0.581 & 0.092 & $0.000^{*}$ \\
Selective exposure & -0.116 & 0.072 & 0.105 \\
Justification & -0.522 & 0.066 & $0.000^{*}$ \\
\hline
\end{tabular}

$* \mathrm{p}<0.01$

Structural model: The structural model of the relationship between reported dissonance and the postpurchase responses (attitude change, trivialisation, selective exposure, justification) was tested by performing SEM analyses using AMOS. The structural model, as depicted in Figure 1, evaluated the hypothesised regressions (Brijball Parumasur \& Parumasur, 2016). The hypothesised model, as depicted in Figure 1, provided a good fit to the data which indicated that the model represents the data well with $\mathrm{CMIN} / \mathrm{DF}=1.636, \mathrm{RMR}=0.101, \mathrm{GFI}=0.860, \mathrm{RMSEA}=0.057$, a comparative fit of CFI $=0.959$ and TLI of 0.953 . Table 3 and Figure 1 depict the standardised regression coefficients estimated by SEM analyses using AMOS. The process of analysis assumes a causal structure between the constructs and enables the estimation of direct effects as depicted in Figure 1. Figure 1 includes both reported dissonance and reported satisfaction as both are part of post-purchase evaluation. However, in accordance with the jurisdiction of this study, the SEM structure depicts the regression estimates extending from reported dissonance only.

Figure 1: Maximum Likelihood Regression (MLR) Estimates for the hypothesized model

POST-PURCHASE POST-PURCHASE RESPONSE

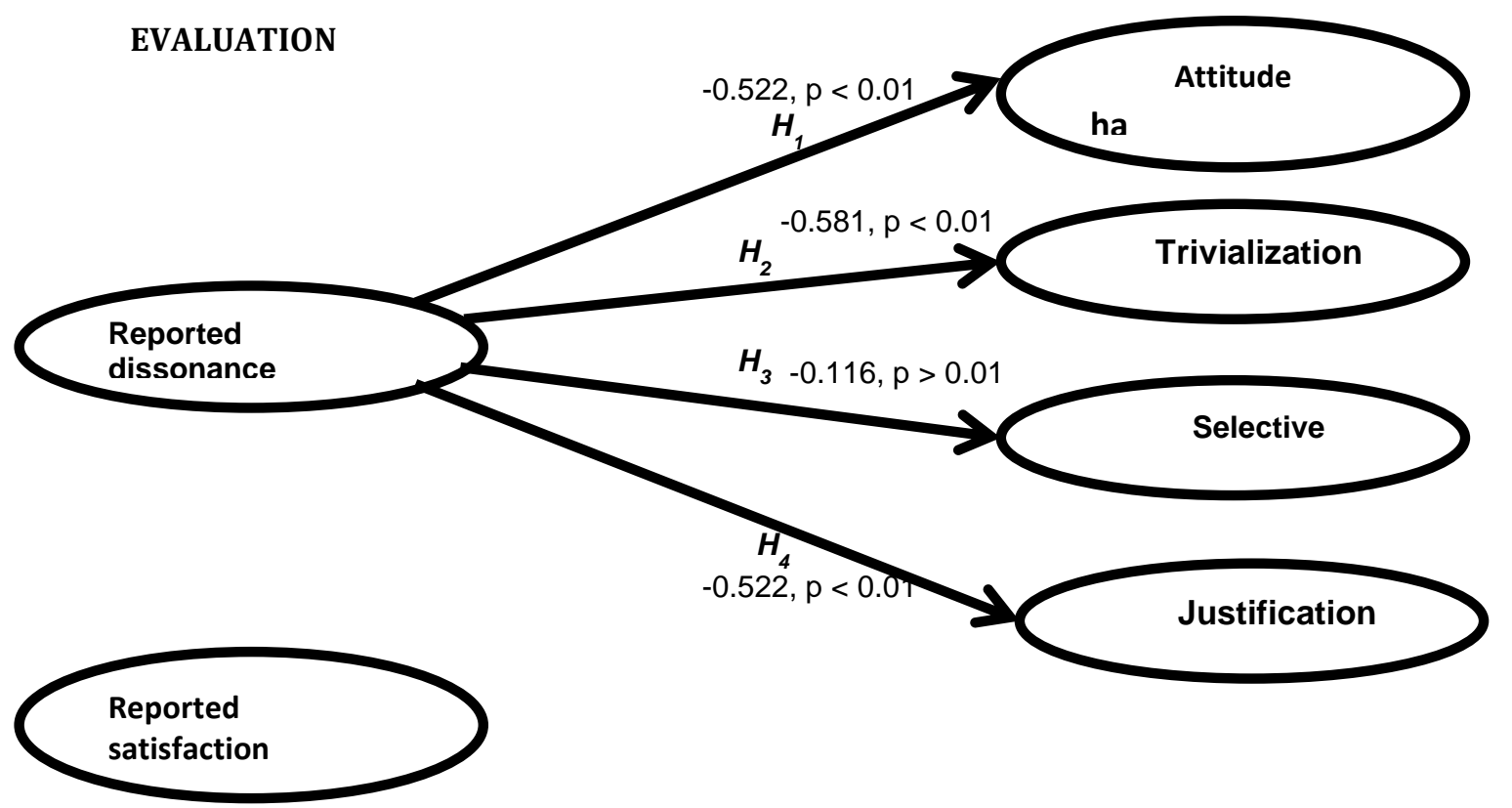

The structural model indicates that there is a significant, inverse and moderate relationship between reported dissonance and attitude change at the $1 \%$ level of significance. Hence, Hypothesis 1 may be 
accepted. The implication is that as the level of reported dissonance increases, the motivation to change one's attitude in favour of the purchased brand decreases. Furthermore, there is a significant, inverse and moderate relationship between reported dissonance and trivialisation at the $1 \%$ level of significance. Therefore, Hypothesis 2 may be accepted. As anticipated, the results imply that as the level of reported dissonance increases, the motivation to minimise the importance of the forgone attractive alternatives or to reduce the unhappiness with the unattractive features in the chosen motor vehicle decreases. In addition, reported dissonance and justification are significantly and inversely related with moderate strength at the $1 \%$ level of significance. Hence, Hypothesis 4 may be accepted. The implication is that as reported dissonance increases, the motivation to justify the incorrect choice and not having made another selection decreases. However, the structural model indicates that there is no significant relationship between reported dissonance and selective exposure. Hence, Hypothesis 3 may not be accepted. As previously indicated, a substantial amount of variation in the model is explained by the relationships depicted in the model and the correlations support the hypotheses. Although the structural model supports 3 of the 4 hypotheses, the model accounts for $70.12 \%$ of the total variance thereby providing support for the model's fit.

Discussion: The results of the study, based on correlation, indicate that negative post-purchase evaluation or reported dissonance is inversely and significantly related to all post-purchases responses (attitude change, trivialization, selective exposure, justification) respectively. As predicted, the relationships are inverse because as the level of reported dissonance increases, consumers are less motivated to engage in postpurchases responses. This may be attributed to intense disillusion, anxiety (Hawkins et al., 2001; Hoelzl et al., 2011; Lamb et al., 2008; Solomon et al., 2006) and unhappiness with the choice which cannot be reduced by adopting any of the post-purchase responses. Such a response is especially likely if the purchase is an expensive one that demands a large capital outlay where the finance could have been used for other purchases and when several attractive alternatives were rejected in making the current unfulfilling choice (Blackwell et al., 2006; Schiffman \& Wisenblit, 2015). The results of the study also indicate that consumers are most likely to engage in justification, attitude change and trivialization and least likely to engage in selective exposure.

In this study, structural equation modeling also confirmed significant, inverse relationships between the level of reported dissonance and the post-purchase responses of attitude change, trivialization and justification with all having moderate strengths. However, structural equation modeling did not confirm a significant relationship between reported dissonance and selective exposure. As anticipated, the causal structure enabled the estimation of the direct effects from reported dissonance to attitude change, trivialization and justification with moderate strength and inverse direction. The implication is that the consumer after the purchase will only reevaluate the chosen brand more favorably than alternatives (attitude change) and/or decrease the importance of the elements involved in the dissonant relations and/or add cognitions to make the attitude-behaviour relationship seem more rational (trivialization) and/or engage in selective exposure or justify the decision if the possibility of reestablishing congruence in cognitions still exists. In other words, the results indicate that there is a threshold beyond which buyers will recognize that any attempts to engage in post-purchase responses (attitude change, trivialization, selective exposure, justification) will be futile. Simon et al. (1995) maintain that consumers are more likely to trivialize when the opportunity to evaluate the salience of the cognitions precedes the opportunity to reflect their attitude. It is clearly evident though, that reported dissonance inversely impacts on post-purchases responses (attitude change, trivialization, selective exposure, justification) and a buyer may engage in any one or a combination of post-purchase strategies in attempts to restore congruence and reduce stress caused by the dissonance. The SEM structure did not espouse the relationship between reported dissonance and selective exposure and this may be attributed to the constant exposure of online and other information such as social media that reduces one's opportunity to be selective over what one wants to be exposed to.

\section{Recommendations and Conclusion}

First and foremost, marketing managers should try to reduce the level of dissonance experienced by high involvement buyers. This can be done by presenting the consumer with facts about the product, clearly indicating the pros and cons and not engaging in exaggeration regarding the product's features or 
performance. The buyer should also not be rushed into a high-end purchase decision and should be encouraged to ask as many questions as possible. Even after the purchase, after sales service is integral. Since it is evident from this study that consumers do engage in post-purchase responses (attitude change, trivialization, selective exposure, and justification) it is imperative to:

- Maintain continuous interaction with the new product buyer after the purchase to reinforce the positive features of the product and its performance strengths. Doing this reinforces buyer confidence.

- Assign a product and service manager to each buyer so that any doubts or concerns can be cleared as soon as they arise. These individuals must be easily accessible and reached otherwise doubts may snowball and the converse may be achieved.

- Ensure that advertisements are widely spread through various channels so as to reinforce the correctness of the choice. Short message service (SMS), multimedia messaging service (MMS) and electronic-mail communications should be just enough to inform the new buyer without overloading his/her mail box.

- Make realistic and accurate comparisons with other products on the market if asked a direct question. Provide the facts without over-stating any product specifications.

- Note that the instant availability of online information and continuous exposure to information may simplify or reduce the role of selective exposure. This perhaps explains the lack of a relationship between reported dissonance and selective exposure in the SEM structure. It is important to ensure that websites are user-friendly and easy to navigate.

- Note that the inverse relationship between reported dissonance and post-purchase responses imply that beyond a certain level of dissonance, buyers will not be motivated to reduce their felt dissonance. This can result in private or public complaint behaviour, future brand switching or negative word-of-mouth communication. Dealerships must be trained to manage such scenarios because complaint behaviour and negative word-of-mouth communication can damage a brand if not effectively managed.

In today's economic climate, the importance of making the correct decision regarding a high involvement purchase becomes more pronounced and the potential for regret, stress and dissonance increases. The most obvious strategy to reduce dissonance and the need to engage in post-purchase responses (attitude change, trivialization, selection exposure, justification) is for the consumer to effectively search for and utilize the readily available information and make an informed decision and for marketers to be ethical in their interactions with prospective buyers and provide factual, complete and honest information.

Limitations of the study: This study focuses on the impact of reported dissonance on post-purchase responses (attitude change, trivialization, selective exposure, justification) after a high involvement purchase decision. It is suggested that the validated instrument be used to assess whether these post-purchase responses are adapted to a lesser or greater extent in habitual or limited consumer decision-making. It is anticipated that these post-purchase responses will be adapted to a lesser extent because an incorrect decision in habitual or limited decision-making can easily be rectified in the next purchase and the product purchase does not involve a large capital outlay. However, the product being purchased and one's involvement with the product also plays an important role in the level of reported dissonance and postpurchase responses.

\section{References}

Aronson, E. (1968). The Social Animal (5th ed), New York: W.H. Freeman \& Company.

Assael, H. (1992). Consumer Behaviour and Marketing Action (4 ${ }^{\text {th }}$ ed), Boston: PWS-KENT Publishing Company.

Bell, G. D. (1967). The automobile buyer after the purchase. Journal of Marketing, 31, 12-16.

Blackwell, R. D., Miniard, P. W. \& Engel, J. F. (2006). Consumer Behavior (10 ${ }^{\text {th }}$ ed), Australia: Thomson SouthWestern.

Bollen, K. A. (1989). Structural Equations with Latent Variables, New York: John Wiley and Sons.

Brehm, J. W. (1992). An Unidentified Theoretical Object. Psychological Inquiry, 3(4), 314-315.

Brehm, J. W. \& Cohen, A. R. (1962). Explorations in Cognitive Dissonance, New York: Wiley and Sons. 
Brijball, S. (2003). The level of importance attached to price and quality in purchasing behaviour. South African Journal of Industrial Psychology, 29(1), 93-99.

Brijball, S. (2000). Consumers' perceptions of personal decision-making: Its relation to cognitive dissonance. South African Journal of Industrial Psychology, 26(2), 37-43.

Brijball Parumasur, S. \& Parumasur, N. (2016). Scale development, validation and use of structural equation modelling to test the impact of consumer confidence and persuasibility on dissonance. Journal of Economics and Behavioral Studies, 8(1), 58-68.

Brijball Parumasur, S. \& Roberts-Lombard, M. (2012). Consumer Behaviour (2 ${ }^{\text {nd }}$ ed), Cape Town, South Africa: Juta and Company Ltd.

Brown, G. H. (1961). The Automobile Buying Decision within the family, In Nelson, N. Foote ed. Household Decision-making (pp. 193-100), New York: University Press.

Browne, M. W. \& Cudeck, R. (1993). Alternative ways of assessing model fit, In K.A. Bollen \& J.S. Long (Eds.), Testing structural equation models (pp. 136-162), Newsbury Park, CA: Sage.

Byrne, B. M. (1994). Structural equation modeling with EQS and EQS/Windows, Thousand Oaks, CA: Sage Publications.

Cooper, J. \& Fazio, R. H. (1984). A new look at dissonance theory, In L. Berkowitz (Ed), Advances in Experimental Social Psychology, 17, 229-266. Orlando, FL: Academic.

Donoghue, S., de Klerk, H. M. \& Ehlers, L. (2008). Consumers' perception of the functional and symbolic performance failure of major electrical household appliances. Journal of Family Ecology and Consumer Sciences, 36, 40-48.

du Plessis, P. J. \& Rousseau, G. G. (2003). Buyer Behaviour: A multi-cultural approach (3rd ed), Oxford, New York: Oxford University Press.

Dubey, A. D. (2014). Young consumers' decision-making behaviour towards casual wear buying in Uttar Pradesh, India, Amity Global Business Review, February, 56-62.

Engel, J. F. (1963). Are Automobile purchasers dissonant consumers? Journal of Marketing, 27, 55-58.

Engel, J. F. \& Blackwell, R. D. (1982). Consumer Behavior (4th ed), Chicago: The Dryden Press.

Ehrlich, D., Guttman, I., Schonbach, P. \& Mills, J. (1957). Post Decision Exposure to Relevant Information. Journal of Abnormal and Social Psychology, 54, 98-102.

Festinger, L. (1957). A theory of cognitive dissonance, Evanston, IL: Row, Peterson.

Frey, D. (1982). Different levels of cognitive dissonance, information seeking and information avoidance. Journal of Personality and Social Psychology, 43, 1175-1183.

Frey, D., Kumpf, M., Irle, M. \& Gniech, G. (1984). Re-evaluation of decision alternatives dependent upon the reversibility of a decision and the passage of time. European Journal of Social Psychology, 14(4), 447450.

Geva, A. \& Goldmann, A. (1991). Duality in consumers' post-purchase attitude. Journal of Economic Psychology, 12(1), 141-164.

Ginter, J. L. (1974). An experimental investigation of attitude change and choice of a new brand. Journal of Marketing Research, 11, 30-40.

Goethals, G. R. \& Cooper, J. (1975). When dissonance is reduced: The timing of self-justificatory attitude change. Journal of Personality and Social Psychology, 32, 261-367.

Greenwald, H. J. (1969). Dissonance and relative versus absolute attractiveness of decision alternatives. Journal of Personality and Social Psychology, 11, 328-333.

Hansen, T. (2005). Perspectives on consumer decision making: An integrated approach. Journal of Consumer Behaviour, 4(6), 420-437.

Hawkins, D. I., Best, R. J. \& Coney, K. A. (2001). Consumer behaviour: Building marketing strategy (8th ed), Boston: Irwin/McGraw-Hill.

Hawkins, D. I. \& Mothersbaugh, D. L. (2013). Consumer Behavior: Building Marketing Strategy (12th ed), New York, NY: McGraw-Hill International Edition.

Heitmann, M., Lehmann, D. R. \& Hermann, A. (2007). Choice goal attainment and decision and consumption satisfaction. Journal of Marketing Research, 44, 234-250.

Hoelzl, E., Pollai, M. \& Kastner, H. (2011). Hedonic evaluations of cars: Effects of payment mode on prediction and experience. Psychology and Marketing, 28(11), 1113-1127.

Horton, R. L. (1984). Buyer Behaviour: A Decision-Making Approach, United States of America: Charles E. Merrill Publishing Company. 
Hoyer, W. D., MacInnis, D. J. \& Pieters, R. (2013). Consumer Behavior (6 $6^{\text {th }}$ ed), Australia: South-Western Cengage Learning.

Hu, L. \& Bentler, P. M. (1999). Cutoff criteria for fit indexes in covariance structure analysis: Conventional criteria versus new alternatives. Structural Equation Modeling, 6(1), 1-55.

Koklič, M. K. \& Vida, I. (2009). A strategic household purchase: Consumer house buying behaviour. Managing Global Transitions, 7(1), 75-96.

Kunda, Z. (1987). Motivated inference: Self-serving generation and evaluation of causal theories. Journal of Personality and Social Psychology, 61, 212-215.

Ladhari, R. (2007). The effect of consumption emotions on satisfaction and word-of-mouth communication. Psychology and Marketing, 24, 1085-1108.

Lamb, C. W., Jr., Hair, J. F., Jr., McDaniel, C., Boshoff, C. \& Terblanche, N. S. (2008). Marketing (3rd South African ed), Cape Town, Southern Africa: Oxford University Press.

Laufer, D. (2002). Are antecedents of consumer dissatisfaction and consumer attributions for product failures universal? Advances in Consumer Research, 29(1), 312-317.

Lord, C. G., Ross, L. \& Lepper, M. R. (1979). Biased assimilation and attitude polarization: The effects of prior theories on subsequently considered evidence. Journal of Personality and Social Psychology, 37, 20982109.

Lowe, R. \& Steiner, I. (1968). Some effects of the reversibility and consequences of decisions on post-decision information preferences. Journal of Personality and Social Psychology, 3, 172-179.

Ndubisi, N. O. \& Ling, T. Y. (2006). Complaint behaviour of Malaysian consumers. Management Research News, 29(1/2), 65-76.

Peter, J. P. \& Olson, J. C. (2010). Consumer Behavior \& Marketing Strategy (9th ed), Boston: McGraw-Hill.

Schiffman, L. \& Kanuk, L. (2014). Consumer Behaviour: Global and Southern African Perspectives, Cape Town, South Africa: Pearson.

Schiffman, L. G. \& Wisenbalt, J. L. (2015). Consumer Behavior (11th ed), Boston: Pearson.

Simon, L., Greenberg, J. \& Brehm, J. (1995). Trivialization: The forgotten mode of dissonance reduction. Journal of Personality and Social Psychology, 68(2), 247-260.

Solomon, M., Bamossy, G., Askegaard, S. \& Hogg, M. K. (2006). Consumer Behaviour: A European Perspective (3rd ed), Harlow, England: Prentice Hall, Financial Times.

Soscia, I. (2007). Gratitude, delight, or guilt: The role of consumers' emotions in predicting postconsumption behaviors. Psychology and Marketing, 24, 871-894.

Traylor, M. B. (1981). Product involvement and brand commitment. Journal of Advertising Research, 21(6), 51-56.

Ullman, J. B. (2001). Structural equation modeling, In B.G. Tabachnick \& L.S. Fidell (2001), Using Multivariate Statistics (4th ed, pp. 653- 771), Needham Heights, MA: Allyn \& Bacon.

Van der Walt, A., Strydom, J. W., Marx, S. \& Jooste, C. J. (1996). Marketing Management (3 ${ }^{\text {rd }}$ ed), Republic of South Africa: Juta and Company, Ltd.

Venkatesan, M. (1973). Cognitive Consistency and Novelty Seeking, In S. Ward \& T.S. Robertson (Eds), Consumer Behavior: Theoretical Sources, Englewood Cliffs, New Jersey: Prentice-Hall, Inc.

Walters, C. G. \& Bergiel, B. J. (1989). Consumer Behaviour: A Decision-Making Approach, Cincinnati: SouthWestern Publishing Company.

Wang, Q. \& Shukla, P. (2013). Linking sources of consumer confusion to decision satisfaction: The role of choice goals. Psychology and Marketing, 30(4), 295-304.

Wicklund, R. A. \& Brehm, J. W. (1976). Perspectives on cognitive dissonance, Hillsdate, N.J.: Lawrence Erlbaum Associates, Inc.

Wilkie, W. L. (1990). Consumer Behaviour (2nd ed), New York: John Wiley and Sons.

Wright, E. F., Rule, B. G., Fergusan, T. J., McGuire, G. R. \& Wells, G. L. (1992). Misattribution of dissonance and behaviour-consistent attitude change. Canadian Journal of Behavioural Science, 24(4), 456-464.

Zajonc, R. B. (1960). The concepts of balance, congruity and dissonance. Public Opinion Quarterly, 24, 280296.

Zaltman, G. \& Wallendorf, M. (1983). Consumer Behaviour: Basic Findings and Management Implications, New York: John Wiley and Sons.

Zeithaml, V. A., Bitner, M. J. \& Gremler, D. D. (2006). Services Marketing: Integrating customer focus across the firm, Boston: McGraw-Hill. 